\title{
Exploring the Relationship Between Professional Development Experience and Skills in Educational Technology Integration Among Primary EFL Teacher
}

\author{
Xuan Zhou \\ College of Education and Human Development, Texas A\&M University, TX, USA \\ ORCID: 0000-0002-7428-083X \\ Yolanda Padron \\ College of Education and Human Development, Texas A\&M University, TX, USA \\ ORCID: 0000-0003-3354-519X \\ Hersh Waxman \\ College of Education and Human Development, Texas A\&M University, TX, USA \\ ORCID: 0000-0002-9872-9224
}

Received: 19 Jul 2021

Accepted: 26 Sep 2021

\begin{abstract}
The purpose of this study was to investigate whether there are differences in professional development (PD) opportunities afforded to English as a Foreign Language (EFL) teachers based on years of teaching experience related to foreign language teaching. Semi-structured interviews were conducted in seven primary schools with 60 primary EFL teachers in a middle-sized urban school district in China. Descriptive statistics and multiple Chi-square tests were used in the study. The results indicated that more experienced primary EFL teachers had the least technological pedagogical knowledge, which is contrary to the traditional concept that more experienced teachers have better teaching knowledge. The study suggests the need to support EFL teachers in China with technology-based PD training including teachers with varied years of teaching experience, in order to enhance their instructional skills.
\end{abstract}

Keywords: EFL, TPACK, education technology, professional development, teacher training

\section{INTRODUCTION}

According to a recent report, there are about 1.35 billion people worldwide who speak English either natively or as a second language (Statista Research Department, Mar 3, 2021). In China, English had been learnt by a tremendous dominant of foreign-language learners in different regions, with the proportion ranging from an $82.7 \%$ to $98.7 \%$ (SGO, 2006). "In terms of the number of learners of foreign languages, English is the most popular foreign language in China" (Wei \& Su, 2012, p. 11). According to Wei and Su, in Mainland China, there are more than 390 million people learning English as a foreign language (EFL). Therefore, to meet the needs of the large population learning EFL in China, the quality of teaching EFL has become imperative.

In 2018, the Ministry of Education of China launched the National Education Informatization 2.0 Action Plan (Education informatization 2.0) for K-12 schoolteachers, which established a standard system and aimed at promoting the training of information technology application skills for K-12 schoolteachers across the 
country. This policy reform is intended to comprehensively improve the information technology literacy of both teachers and students, as well as to promote their technology competency.

Researchers continue argue that integrating technology in education is a way making teacher's teaching more effective and benefiting students learning (Cuban, 2001). In the new era, education is strongly supported by technology infused learning as educational technology continues to be used extensively in classroom instruction. Research studies assert that teachers who integrate educational technology in classroom teaching profoundly affect their teaching effectiveness and student achievement, especially for teaching English learners (ELs) (Jabbari et al., 2017). For example, the experiences of students applying digital tools to learning English have been found to be positive and rewarding (Golonka et al., 2014). ELs enjoy participating in blogs and other online platforms because the feedback they received from their classmates and teachers helped them to develop better writing skills (Angelova \& Zhao, 2016). Likewise, digital learning experiences provide an authentic learning environment for students in which they can interact with their native speakers as well as their teacher and peers in developing their English listening and speaking skills (Golonka et al., 2014). Hence, using information and educational technology in English teaching and learning provides abundant interactive materials that motivate students and make learning a second or foreign language more enjoyable. Since, English as a Foreign Language (EFL) curricula have been established across many countries, EFL teachers' knowledge of integrating technology into classroom teaching plays an important role in the students' language development (Rienties et al., 2020).

At the same time, PD has been shown to influence teacher efficacy beliefs about their own ability in classroom teaching, classroom management, and student engagement. Karimi (2011) conducted a study which indicated that teachers who received PD training had significant higher teacher efficacy than those who did not, meaning that PD initiatives has significant effects on enhancing EFL teachers' sense of efficacy in teaching. Teacher efficacy is closely connected to a teacher's knowledge and skills in a specific domain since it refers to a teacher's desire to apply his/her teaching skills appropriately and effectively. Thus, PD training has significant impact in improving EFL teachers' skills and self-perceived abilities.

Therefore, the quality of teacher professional development (PD) has become an important educational topic as teachers continue to increasingly be held accountable for the academic achievement of their students. Ongoing PD is critical in enhancing teachers' technology competence and confidence, thus promoting the use of technology in their teaching. Unless teachers received sufficient training in coping with technology and teaching skills, they will not be confident and comfortable using educational technology in EFL classroom teaching (Li, 2014). However, although the policy NEIAP 2.0 has been implemented, there is little evidence across varied professional experience levels that EFL teachers are well equipped to teach digitally, and that they are receiving adequate PD training in how to integrate technology in their EFL classes in China (Xu \& Sun, 2019). It is essential for schools to understand that EFL teachers who lack the skills to integrate technology in their teaching may impede student's language learning. The objectives of this study were:

1. To determine whether there are differences in EFL teacher's PD opportunities depending on EFL teachers' teaching experiences in primary schools in China.

2. To investigate EFL teacher PD opportunities related to Technological, Pedagogical and Content Knowledge (TPACK)

\section{Technological, Pedagogical and Content Knowledge (TPACK)}

Three domains of knowledge have been identified in order to successfully integrate technology in instruction. These three domains are: Pedagogical Knowledge (PK), Content Knowledge (CK), and Technological Knowledge (TK). In addition, the intersection of these three domains is Pedagogical Content Knowledge (PCK), Technological Content Knowledge (TCK), and Technological Pedagogical Knowledge (TPK) (Bostancıoğlu \& Handley, 2018). TPACK is built upon the intersection between the aforementioned six domains (Figure 1). Mishra and Koehler (2006) concluded that TPACK is the basis of effective teaching with technology, and requires an understanding of the following five technology related concepts; pedagogical methods that use technologies in productive ways to teach content, that awareness of things makes concepts 


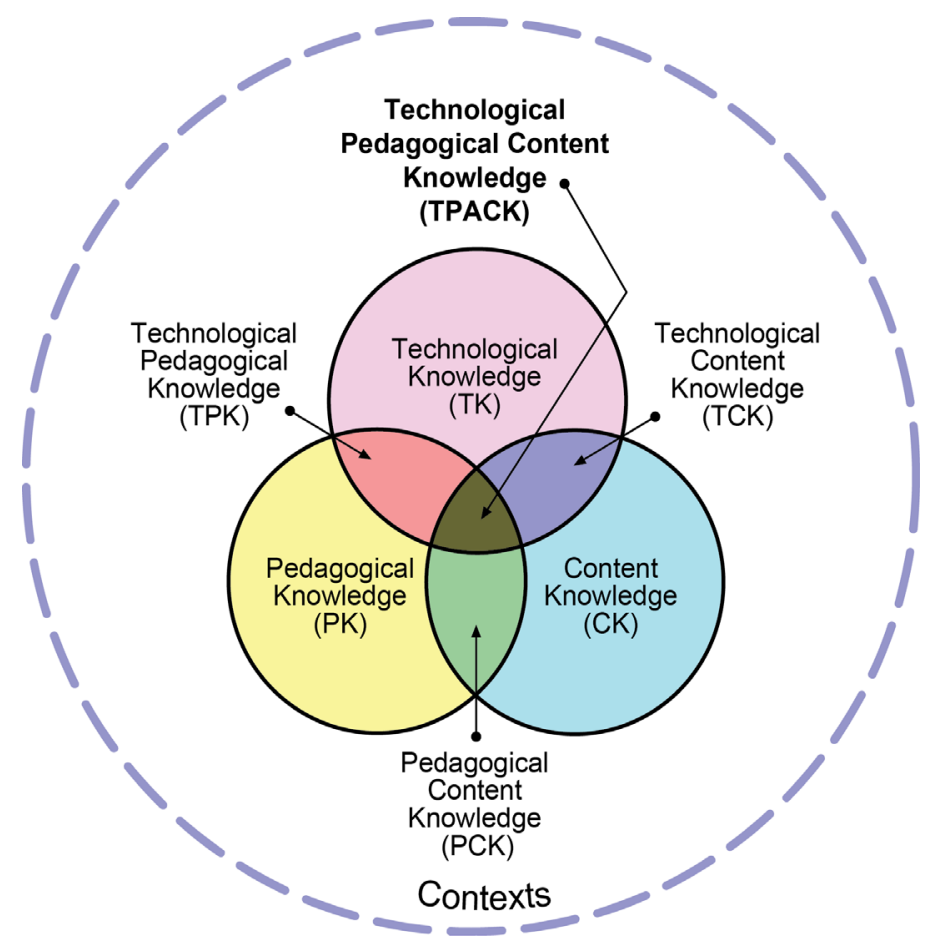

Figure 1. The TPACK Image (Reproduced by permission of the publisher, (c) 2012 by tpack.org)

easy to learn, how technology can alleviate some of the problems that students confront, knowledge of students' prior experience, and knowledge of how technology can use to build upon existing knowledge to develop new epistemologies or strengthen old ones.

\section{TPACK and EFL Teachers}

Many studies have been conducted to examine EFL teachers' level of technology integration in classroom teaching through the lens of TPACK. Research found that teachers who are able to proficiently use the technology related to the content area positively influence the academic achievement of the students (Akturk \& Ozturk, 2019). According to Wu and Wang (2015), however, EFL teachers lack the requisite technological knowledge to further enhance their TPACK, and they need to focus more on using technology for creating opportunities for students to use English language meaningfully and authentically instead of merely motivating students. Furthermore, studies have revealed that although EFL teachers perceived confidence in TPACK, they had low confidence in CK, TK, and TPK (Cheng, 2017), which may result in inability to integrate the subsections of the TPACK framework and impede their ability to apply of TPACK skills. Hsu (2016) indicated that EFL teachers possessed appropriate TPK, however, they had limited understanding in TK, PK, and CK, which are the core areas in the TPACK framework. Therefore, unless EFL teachers have a thorough understanding of the interrelationship of TK, PK, and CK, educational technology cannot be used effectively to deliver meaningful instruction (Debbagh \& Jones, 2018).

The traditional perspective is that teachers who have more teaching experience possess better teaching skills (Cheng, 2017; Kini \& Podolsky, 2016). However, the findings of recent studies on the relationships between teaching experience and teacher TPACK level refute this assumption. Yuksel and Yasin (2014) found that more experienced teachers had lower TPACK skills on average than other teacher groups who possessed less teaching experience. According to Akturk and Ozturk (2019), who evaluated EFL teachers' TPACK level and its relationship with teacher's professional experience in Turkey, EFL teachers who had fewer years of teaching experience had higher TK and TPACK levels than teachers who had been working for 21 years or more. The results of Akturk and Ozturk's (2019) study show that teachers who were in their first 10 years of teaching had higher levels of PK, TPK, and TCK than teachers who had been working more than 21 years in the profession. Similarly, according to Nazari et al. (2019), there was a significant difference in perceived 
TPACK between novice and experienced EFL teachers. In their study, experienced Iranian EFL teachers were found to have significantly higher PK and PCK. In contrast, novice teachers had significantly higher levels of TK, TCK, TPK, and TPACK.

Furthermore, studies also found that the EFL teachers were unable to effectively integrate technology into their teaching with appropriate pedagogies, and that there was a critical need to provide them with relevant PD activities in TPACK-EFL (Nazari et al., 2019). The PD of TPACK and other technology-infused training for EFL teachers has been shown in recent studies to have a significant impact on improving teaching effectiveness. Teachers, for example, who have participated in the training program felt more confident about enhancing students' learning outcomes through the use of technology (Ansyari, 2015). Studies also reported that teachers perceived that their ability to successfully apply TPACK increased after receiving TPACK related training courses (Caromawati, 2017; Liu \& Kleinsasser, 2015), supporting claims that a PD program based on the TPACK framework should be advocated for EFL teachers. In a more recent study, Baracaldo Guzmán (2019) also found that the PD experience in developing TPACK-EFL skills helped teachers expand knowledge and skills and provided better language teaching. Thus, the TPACK-EFL model used in PD training provides EFL teachers with helpful insights to design content-based learning activities that meet ELs' needs, and effectively integrate technology into lesson planning.

Little research, however, has been conducted as to whether Chinese EFL teachers receive adequate PD training opportunities in TPACK that is attributed to their teaching experience or. Moreover, most studies that have been conducted do not address teacher's integration of technology related to TPACK in teaching EFL in China. Considering the recent policy implementation in China which aims to improve the use of educational technology in classroom teaching, it is important to investigate the use of technology in current EFL teaching. The present study aims to examine the differences of TK, TPK, and TPACK among EFL teachers depending on their teaching experience. It also investigates the differences of PD opportunities in teaching EFL digitally among teachers with varied teaching experience, in order to better support EFL teachers to develop their instructional/technological skills. Thus, two main research questions are proposed in this study as follows:

- Do Chinese EFL teacher's TPACK differs significantly according to teaching experiences?

- Do PD opportunities offered Chinese EFL teacher's in TPACK related training differs significantly according to teaching experiences?

\section{METHODS}

\section{Context}

Public schools were the focus of this study since these are dominant in the Chinese education system. This study was conducted in seven public primary schools from a middle-sized school district located in an urban area in east China (on average, approximately 1300- 1500 students are enrolled per school). EFL courses are required of all students starting in the third grade, and all of the ELs at schools are Mandarin Chinese monolinguals. On average, class sizes in this school district are large with 45-50 students per teacher. Each EFL teacher usually teaches two to four 45 -minute class periods a day.

\section{Participants}

There is a total of 60 certified full-time EFL teachers participated in this study (female $=49$, male $=11$ ). Participants volunteered to participate in the study which consisted of individual interviews conducted during the teachers off duty time. The teaching grade-level composition of the teachers who took part in the study was as follows: third grade $(n=18)$, fourth grade $(n=19)$, fifth grade $(n=18)$, and sixth grade $(n=18)$. There was some overlap due to some participants teaching multiple grade levels. In addition, this study grouped participants into four categories based on their years of teaching experience. That is, $22.8 \%$ of the teachers were in Group 1 with beginning teaching experience defined as having $0-5$ years in the classroom, 33.3\% of the teachers were in Group 2 with 6-10 years of experience, $21.1 \%$ of them were in Group 3 having 11-15 
Table 1. Components of the questionnaire

\begin{tabular}{ll}
\hline Section Names & Sample Questions \\
\hline Technological knowledge (TK) & Do you know how to edit visual images and videos? \\
$\begin{array}{l}\text { Technological pedagogical } \\
\text { knowledge (TPK) }\end{array}$ & $\begin{array}{l}\text { Do you use different kinds of educational technology tools in teaching, such as } \\
\text { network tools, computer software or electronic whiteboard? How do you use these? }\end{array}$ \\
$\begin{array}{ll}\text { Technological pedagogical } \\
\text { content knowledge (TPACK) }\end{array}$ & $\begin{array}{l}\text { Do you use electronic tools to measure students' learning? If so, what/how do you } \\
\text { Teachers PD opportunities of four aspects of listening, reading, writing and speaking respectively) }\end{array}$ \\
\begin{tabular}{ll} 
TPACK & Have you had training on how to use technology to support teaching and to improve \\
\hline
\end{tabular}
\end{tabular}

years of experience, and $22.8 \%$ were in Group 4 which was categorized for advanced high teaching participants with more than 16 years of classroom teaching experience.

\section{Instrument}

Semi-structured interviews were used in this study. The interview consisted of 20 main questions and followup probing questions. The interview was adapted from two instruments: Technological Pedagogical Content Knowledge (TPACK) for English as a Foreign Language (EFL) (Bostancıoğlu \& Handley, 2018) and EFL teachers' Current Practice and Application of E-Educology of Foreign Languages (CPA-EEFL) (Kabakci Yurkakul et al., 2012). Questions from the instruments were selected that addressed teacher's TPACK and opportunities related to TPACK training. The two instruments use a five-point Likert Scale, ranging from 'strongly agree' to 'strongly disagree' and were adapted to more accurately reflect the Chinese context. EFL- TPACK contained 36 items with a reported overall Cronbach's $\alpha$ coefficient of .94 (Bostancıoğlu \& Handley, 2018). CPA-EEFL consisted of 33 items with the good reliability at Cronbach's $\alpha=.95$ (Kabakci Yurdakul et al., 2012). Both instruments are self-reporting instruments that focus on the assessment of teacher's English language teaching and attitudes towards TPACK as well as its related PD training. The components of the interview and the samples questions for each section were listed in Table 1. Basically, it focused on assessing teachers' knowledge in reference to: a) technology use, b) technological and pedagogical knowledge, c) technological, pedagogical and content integration; d) teachers' attitudes towards TPACK, and e) teachers' PD training opportunities and needs.

\section{Data Collection/Data Analysis}

Each in-service EFL teacher was interviewed in English for approximately 30 minutes. All interviews were recorded. Participants' responses were transcribed and reviewed for accuracy several times. Statistical analysis of quantitative coding results was conducted. In this study, teaching experience groups were coded from beginning level (1) to advanced high level (4). In assessing teacher's TPACK, questions such as whether participants use any soft/hard-ware in the daily teaching was coded as Yes $=1$, and $N o=0$ for each device respectively, if they use such as e-textbook, Office Software, smartboard, and other 5 devices in class or not. For the questions asking about whether they have experience about a certain activity, or if they use any particular strategy in class, answers were coded as $Y e s=1, N o=0$. Also, for some questions asking about a "How to", we collected all the responses and made a list of them; then, we assigned each of the similar response a same alphabetical code so as to be recognized as the sub-question; these sub-questions were measured as a binary variable in the analysis with $Y e s=1, N o=0$. In the second component of the interview, if a question asks about teacher's opinions, positive opinion was coded as $Y e s=1$, and the contrary response was coded as $\mathrm{No}=0$. Finally, for questions that asks about teacher's feeling or perception, answers were coded in numerical order starting from 1 and up to 4 to represent the level in categories from disagree to agree. Multiple Chi-square tests were used to examine the differences between teachers in groups by teaching experiences regarding the teacher's TPACK and opportunities for PD training. 
Table 2. Percentage of EFL teachers having PD training opportunities

\begin{tabular}{lccccc}
\hline \multirow{2}{*}{ Types of PD } & \multicolumn{3}{c}{ Years of Teaching Experience } & \multicolumn{2}{c}{ Total Percentage } \\
\cline { 2 - 5 } & $0-5$ & $6-10$ & $11-15$ & $16+$ & \\
\hline Soft/hard-ware training & $21 \%$ & $75 \%$ & $69 \%$ & $62 \%$ & $58 \%$ \\
ICT training & $14 \%$ & $50 \%$ & $54 \%$ & $23 \%$ & $37 \%$ \\
Online/distance training & $43 \%$ & $70 \%$ & $85 \%$ & $54 \%$ & $47 \%$ \\
Face to face training & $64 \%$ & $65 \%$ & $62 \%$ & $38 \%$ & $53 \%$ \\
\hline
\end{tabular}

\section{RESULTS}

Group differences among different teaching experiences by PD opportunities were examined in this study. In addition, differences were investigated to determine whether years of teaching experience [Group 1(0-5 years) Group 2 (6-10 years) Group 3 (11-15 years) Group 4 (16 years or more)] manifested in a higher level of TPACK.

\section{Q1: Do PD Opportunities Offered Chinese EFL Teacher's in TPACK Related Training Differs Significantly According to Teaching Experiences?}

According to the results shown in Table 2, the percentage of EFL teachers who participated PD training related to TPACK skills during the last year was less than $50 \%$. The training that teachers participated in most often was training related to Soft/hard-ware training (58\%). This was most often reported by teachers who had 6-10 years of teaching experience (75\%), followed by teachers with 11-15 years of teaching experience (69\%). Teachers with the least number of years of experience (0-5) reported receiving few PD opportunities in soft/hard-ware training (21\%). In terms of teachers' training opportunities of informational communication technology (ICT) skills, 37\% reported having experience in the training. This was most often reported by $11-$ 15 years of teaching experience teachers (54\%). Teachers with $0-5$ years of experience reported the least opportunities in receiving ICT training (14\%).

With the respect to the methods of training provided to teachers, less than $50 \%$ teachers reported having opportunities to attend online/distance training. Among those teachers, 11-15 years of experience teachers had the most opportunities (85\%), whereas beginning teachers had the least opportunities (43\%). Additionally, $53 \%$ of teachers stated that they participated face to face training in the past year. Teachers with 6-10 years of experience participated with the most opportunities (65\%), and teachers with more than 16 years' experience participated the least (38\%).

To further examine the differences among teachers with varied teaching experience regarding their PD opportunities, a Chi-square test was conducted. The results from the Chi-Square test (Table 3) indicated that there was no difference between groups of teachers who received soft/hard-ware training, therefore the null hypothesis was rejected $\left(p<0.01, X^{2}=13.77\right)$. Further, the null hypothesis of no differences between groups in receiving ICT training was rejected $\left(p<0.05, X^{2}=9.43\right)$. Also, it failed to retain the null hypothesis for no differences between groups in Online/Distance training $\left(p<0.05, X^{2}=9.61\right)$. In other words, we found that there are significant differences between teachers with different years of experience in receiving soft/hardware training, ICT training, and Online/Distance training opportunities. Teachers with 6-15 years of teaching experience were found to have more training opportunities than those beginning teachers and teachers with more than 16 years' experience.

Beginning teachers reported that they have fewer PD opportunities than other groups due to a lack of access to obtain the information. Nearly half of the beginning teachers were the first-year teachers $(46 \%, N=6)$ and most of them reported that they did not have any PD experiences except for the weekly meeting of the content department which is mainly focused on CK. According to responses of teachers in Group 4, some of them do not think technology plays an important function in classroom teaching. They preferred to use more traditional ways of instruction. More experienced teachers in Group 4 said that they had little technology training in their earlier careers, so they are not likely to rely on teaching via technology. Additionally, a few teachers in Group 4, with the greatest years of experience, indicated that as the time gets closer to their 
Table 3. Teachers' training opportunities by teaching experience

\begin{tabular}{|c|c|c|c|c|c|c|c|}
\hline \multirow{2}{*}{ Types of PD } & \multirow{2}{*}{$\begin{array}{l}\text { Training } \\
\text { Opportunities }\end{array}$} & \multicolumn{4}{|c|}{ Years of Teaching Experience } & \multirow{2}{*}{$\chi^{2}$} & \multirow{2}{*}{$p$} \\
\hline & & $0-5$ & $6-10$ & $11-15$ & $16+$ & & \\
\hline \multirow{2}{*}{$\begin{array}{l}\text { Soft/hard-ware } \\
\text { training }\end{array}$} & Yes & $3(-3.5)$ & $15(2.2)$ & $9(1.3)$ & $8(-.1)$ & $13.77 * *$ & .003 \\
\hline & No & $12(3.5)$ & $4(-2.2)$ & $3(-1.3)$ & $6(.1)$ & & \\
\hline \multirow[t]{2}{*}{ ICT training } & Yes & $2(-2.2)$ & $10(1.7)$ & $7(1.7)$ & $3(-1.4)$ & $9.43^{*}$ & .024 \\
\hline & No & $13(2.2)$ & $9(-1.7)$ & $5(-1.7)$ & $11(1.4)$ & & \\
\hline \multirow{2}{*}{$\begin{array}{l}\text { Online/distance } \\
\text { training }\end{array}$} & Yes & $6(-2.2)$ & $14(1.1)$ & $11(2.3)$ & $7(-1.2)$ & $9.61^{*}$ & .022 \\
\hline & No & $9(2.2)$ & $5(-1.1)$ & $1(-2.3)$ & $7(1.2)$ & & \\
\hline \multirow[t]{2}{*}{ Face to face training } & Yes & $9(-1.2)$ & $13(1.6)$ & $8(1.0)$ & $5(-1.5)$ & 5.41 & .144 \\
\hline & No & $6(1.2)$ & $6(-1.6)$ & $4(-1.0)$ & $9(1.5)$ & & \\
\hline
\end{tabular}

Note. ${ }^{*} p<.05,{ }^{* *} p<.01, d f=3$. Adjusted standardized residuals appear in parentheses beside group frequencies

Table 4. Percentage of teachers' self-reported TK by teaching experience

\begin{tabular}{lccccc}
\hline \multirow{2}{*}{ Technological Knowledge } & \multicolumn{3}{c}{ Years of Teaching Experience } & \multicolumn{2}{c}{ Total Percentage } \\
\cline { 2 - 4 } & $0-5$ & $6-10$ & $11-15$ & $16+$ & \\
\hline Skilled in image \& video editing & $33 \%$ & $74 \%$ & $58 \%$ & $29 \%$ & $50 \%$ \\
Familiarity of ICT & $47 \%$ & $79 \%$ & $75 \%$ & $36 \%$ & $60 \%$ \\
ICT use in class & $20 \%$ & $53 \%$ & $58 \%$ & $14 \%$ & $37 \%$ \\
\hline
\end{tabular}

Note. ${ }^{*} p<.05,{ }^{* *} p<.01, d f=3$. Adjusted standardized residuals appear in parentheses beside group frequencies

Table 5. Teachers' TK by teaching experience

\begin{tabular}{|c|c|c|c|c|c|c|c|}
\hline \multirow{2}{*}{$\begin{array}{l}\text { Technological } \\
\text { Knowledge }\end{array}$} & \multirow{2}{*}{ Responses } & \multicolumn{4}{|c|}{ Years of Teaching Experience } & \multirow{2}{*}{$\chi^{2}$} & \multirow{2}{*}{$p$} \\
\hline & & $0-5$ & $6-10$ & $11-15$ & $16+$ & & \\
\hline \multirow{2}{*}{$\begin{array}{l}\text { Skilled in image \& } \\
\text { video editing }\end{array}$} & Yes & $5(-1.5)$ & $14(2.5)$ & $7(.7)$ & $4(-1.8)$ & $8.84^{*}$ & .032 \\
\hline & No & $10(1.5)$ & $5(-2.5)$ & $5(-.7)$ & $10(1.8)$ & & \\
\hline \multirow[t]{2}{*}{ Familiarity of ICT } & Yes & $7(-1.2)$ & $15(2.0)$ & $9(1.2)$ & $5(-2.1)$ & $8.52^{*}$ & .036 \\
\hline & No & $8(1.2)$ & $4(-2.0)$ & $3(-1.2)$ & $9(2.2)$ & & \\
\hline \multirow[t]{2}{*}{ ICT use in class } & Yes & $3(-1.5)$ & $10(1.9)$ & $7(1.6)$ & $2(-2.1)$ & $9.44^{*}$ & .024 \\
\hline & No & $11(1.5)$ & $8(-1.9)$ & $5(-1.6)$ & $12(2.1)$ & & \\
\hline
\end{tabular}

Note. ${ }^{*} p<.05,{ }^{* *} p<.01, d f=3$. Adjusted standardized residuals appear in parentheses beside group frequencies

retirement, they do not want to spend extra time learning the latest TK in cooperating with Content and Pedagogy to teach EFL. Thus, it appears that the more experienced teachers in Groups 4 are less willing to acquire and apply TPACK than other groups of teachers. This may account for the less training they reported receiving during the past years.

\section{Q2: Do Chinese EFL Teacher's TPACK Differs Significantly According to Teaching Experiences?}

According to Table 4, EFL teachers TK seems not skilled highly. About half of teachers were not skilled in the application of technologies as well as not frequently applied ICT in class use. Among those teachers who reported skilled in image, and video editing, teachers in Group 2 reported with highest skills (74\%), whereas teachers in Group 4 reported with the lowest (29\%). In addition, teachers with intermediate level of teaching experience (Group 3) uses TK in ICT application most (58\%), but the most advanced teacher group (Group 4) were least in use (14\%).

Statistical significance was also found between teachers' experience and TPACK skills by a Chi-square test. Table 5 shows that there is statistically significance on teacher's TK between teacher groups (i.e., Skilled in image and video editing, $p<0.05, X^{2}=8.84$; Familiarity of ICT, $p<0.05, X^{2}=8.52$; ICT use in class, $p<0.05, X^{2}=$ 9.44). Teachers with intermediate level seems to have the most TK than other groups.

According to the results for TPK reported on Table 6, most teachers stated not having the TPK needed to effectively apply TPACK. Additionally, teachers with intermediate and advanced level of teaching experience reported being skilled in TPK, compared with other two teacher groups in the reported percentages. In the use of multiple types of technology and smartboard for class activities, teachers in Group 3 reported highest 
Table 6. Percentage of teachers' self-reported TPK by teaching experience

\begin{tabular}{lccccc}
\hline \multirow{2}{*}{ Technological Pedagogical Knowledge } & \multicolumn{3}{c}{ Years of Teaching Experience } & \multicolumn{2}{c}{ Total Percentage } \\
\cline { 2 - 4 } & $0-5$ & $6-10$ & $11-15$ & $16+$ & \\
Use multiple types of technology & $27 \%$ & $63 \%$ & $67 \%$ & $29 \%$ & $47 \%$ \\
Smartboard use for class activities & $33 \%$ & $53 \%$ & $67 \%$ & $14 \%$ & $42 \%$ \\
External links use for class activities & $13 \%$ & $58 \%$ & $58 \%$ & $29 \%$ & $40 \%$ \\
Define multimedia instruction & $47 \%$ & $74 \%$ & $92 \%$ & $43 \%$ & $63 \%$ \\
Knowledge of sufficient English learning websites & $20 \%$ & $58 \%$ & $58 \%$ & $21 \%$ & $40 \%$ \\
Use school district's resources & $20 \%$ & $58 \%$ & $42 \%$ & $79 \%$ & $50 \%$ \\
\hline
\end{tabular}

Table 7. Teachers' TPK by teaching experience

\begin{tabular}{|c|c|c|c|c|c|c|c|}
\hline \multirow{2}{*}{$\begin{array}{l}\text { Technological Pedagogical } \\
\text { Knowledge }\end{array}$} & \multirow{2}{*}{ Responses } & \multicolumn{4}{|c|}{ Years of Teaching Experience } & \multirow{2}{*}{$\chi^{2}$} & \multirow{2}{*}{$p$} \\
\hline & & $0-5$ & $6-10$ & $11-15$ & $16+$ & & \\
\hline \multirow{2}{*}{$\begin{array}{l}\text { Use multiple types of } \\
\text { technology }\end{array}$} & Yes & $4(-1.8)$ & $12(1.7)$ & $8(1.6)$ & $4(-1.6)$ & $8.26^{*}$ & .041 \\
\hline & No & $11(1.8)$ & $7(-1.7)$ & $4(-1.6)$ & $10(1.6)$ & & \\
\hline \multirow{2}{*}{$\begin{array}{l}\text { Smartboard use for class } \\
\text { activities }\end{array}$} & Yes & $5(-.8)$ & $10(1.2)$ & $8(2.0)$ & $2(-2.4)$ & $8.77^{*}$ & .032 \\
\hline & No & $10(.8)$ & $9(-1.2)$ & $4(-2.0)$ & $12(2.4)$ & & \\
\hline \multirow{2}{*}{$\begin{array}{l}\text { External links use for class } \\
\text { activities }\end{array}$} & Yes & $2(-2.4)$ & $11(1.9)$ & $7(1.4)$ & $4(-1.0)$ & $9.42 *$ & .024 \\
\hline & No & $13(2.4)$ & $8(-1.9)$ & $5(-1.4)$ & $10(1.0)$ & & \\
\hline \multirow{2}{*}{$\begin{array}{l}\text { Define multimedia } \\
\text { instruction }\end{array}$} & Yes & $7(-.5)$ & $14(1.1)$ & $11(2.3)$ & $6(-1.5)$ & $9.35^{*}$ & .025 \\
\hline & No & $8(-.5)$ & $5(-1.5)$ & $1(-1.5)$ & $8(1.5)$ & & \\
\hline \multirow{2}{*}{$\begin{array}{l}\text { Knowledge of sufficient } \\
\text { English learning websites }\end{array}$} & Yes & $3(-1.8)$ & $11(1.9)$ & $7(1.4)$ & $3(-1.6)$ & $8.73^{*}$ & .033 \\
\hline & No & $12(1.8)$ & $8(-1.9)$ & $5(-1.4)$ & $11(1.6)$ & & \\
\hline \multirow{2}{*}{$\begin{array}{l}\text { Use school district's } \\
\text { resources }\end{array}$} & Yes & $3(-2.8)$ & $11(1.0)$ & $5(-.7)$ & $11(2.4)$ & $11.18^{*}$ & .011 \\
\hline & No & $12(2.8)$ & $7(-1.0)$ & $7(.7)$ & $3(-2.4)$ & & \\
\hline
\end{tabular}

Note. ${ }^{*} p<.05,{ }^{*} p<.01, d f=3$. Adjusted standardized residuals appear in parentheses beside group frequencies

in both aspects (67\%), whereas Group 4 reported both at the least level with $29 \%$ and $14 \%$, respectively. In terms of teachers' knowledge of using external links in class activity and English learning websites for class teaching, teachers with 6-15 years of teaching experience reported higher (58\%) than these two aspects than among the beginning teachers ( $13 \%$ and $21 \%$ ) and most advanced teachers ( $29 \%$ and $20 \%)$. Interestingly, teachers are fairly good at defining multimedia instruction (63\%) and half of them know the support of multimedia instruction from the school district.

According to Table 7, the hypothesis that there are no differences between groups on teachers TPK was rejected by the Chi-square test. Each component of TPK by teacher experience were found with statistical significance (i.e., Use multiple types of technology, $p<0.05, X^{2}=8.26$; Smartboard use for class activities, $p<0.05, X^{2}=8.77$; Use external websites for class activities, $p<0.05, X^{2}=9.42$; Correctly define multimedia instruction, $p<0.05, X^{2}=9.35$; Knowledge of sufficient English learning websites, $p<0.05, X^{2}=8.73$; Use school /district's resources, $\mathrm{p}<0.05, \mathrm{X}^{2}=11.18$ ). In general, teachers in Group 2 and 3 reported the higher TPK than other groups.

In Table 8, EFL teachers appear to use technology in teaching listening skills the most (97\%). However, they were not likely to apply TPACK in teaching speaking (57\%), reading (60\%) and writing skills (32\%) to ELs. Teachers with intermediate and advanced level of teaching experience were evaluated with more skills in TPACK, compared with other two teacher groups in the reported percentages. According to Table 8, in use for speaking, teachers in Group 4 were reported with the highest TPK (79\%), followed by Group 3 teacher (67\%), Group 1 teachers (40\%), and Group 4 (36\%). Among those teachers, 38\% of them prefer to use dubbing as class activities. In teaching reading skills, teachers in Group 3 had the highest percentage in the application of TPK (85\%), and then teachers in Group $2(80 \%)$. Among those teachers, digital picture books were used often for class reading activities (53\%). In terms of teachers' TPK in teaching writing skills, teachers in Group 4 were reported with the least level (21\%). Group 2 was reported the highest (53\%). Of these teachers, word ban on the smartboard is the most often used strategy in teaching writing $(32 \%)$. 
Table 8. Percentage of teachers' self-reported TPACK by teaching experience

\begin{tabular}{lccccc}
\hline Technological Pedagogical and & \multicolumn{3}{c}{ Years of Teaching Experience } & Total Percentage \\
\cline { 2 - 5 } Content Knowledge & $0-5$ & $6-10$ & $11-15$ & $16+$ & $97 \%$ \\
\hline Technology use in listening & $100 \%$ & $95 \%$ & $92 \%$ & $100 \%$ & $50)$ \\
Technology use in speaking & $40 \%$ & $79 \%$ & $67 \%$ & $36 \%$ & $57 \%$ \\
Dubbing for videos & $27 \%$ & $53 \%$ & $58 \%$ & $14 \%$ & $38 \%$ \\
Technology use in reading & $47 \%$ & $80 \%$ & $85 \%$ & $43 \%$ & $60 \%$ \\
Digital picture books & $60 \%$ & $60 \%$ & $25 \%$ & $79 \%$ & $53 \%$ \\
Technology use in writing & $20 \%$ & $53 \%$ & $42 \%$ & $21 \%$ & $32 \%$ \\
Word bank use for writing & $20 \%$ & $47 \%$ & $58 \%$ & $14 \%$ & $32 \%$ \\
\hline
\end{tabular}

Table 9. Teachers' TPACK by teaching experience

\begin{tabular}{|c|c|c|c|c|c|c|c|}
\hline \multirow{2}{*}{$\begin{array}{l}\text { Technological Pedagogical } \\
\text { and Content Knowledge }\end{array}$} & \multirow{2}{*}{ Responses } & \multicolumn{4}{|c|}{ Years of Teaching Experience } & \multirow{2}{*}{$\chi^{2}$} & \multirow[b]{2}{*}{$p$} \\
\hline & & $0-5$ & $6-10$ & $11-15$ & $16+$ & & \\
\hline \multirow{2}{*}{$\begin{array}{l}\text { Technology use in } \\
\text { listening }\end{array}$} & Yes & $15(.8)$ & $18(-.6)$ & $11(-1.1)$ & $14(.8)$ & 2.15 & .542 \\
\hline & No & $0(-.8)$ & $1(.6)$ & $1(1.1)$ & $0(-.8)$ & & \\
\hline \multirow{2}{*}{$\begin{array}{l}\text { Technology use in } \\
\text { speaking }\end{array}$} & Yes & $6(-1.5)$ & $15(2.4)$ & $8(.8)$ & $5(1.8)$ & $8.53^{*}$ & .036 \\
\hline & No & $9(1.5)$ & $4(-2.4)$ & $4(-.8)$ & $9(1.8)$ & & \\
\hline \multirow[t]{2}{*}{ Dubbing for videos } & Yes & $4(-1.1)$ & $10(1.6)$ & $7(1.6)$ & $2(-2.1)$ & $7.96^{*}$ & .047 \\
\hline & No & $11(1.1)$ & $9(-1.6)$ & $5(-1.6)$ & $12(2.1)$ & & \\
\hline \multirow{2}{*}{ Technology use in reading } & Yes & $7(-1.2)$ & $12(.3)$ & $11(2.5)$ & $6(-1.5)$ & $7.92^{*}$ & .048 \\
\hline & No & $8(1.2)$ & $7(-.3)$ & $1(-2.5)$ & $8(1.5)$ & & \\
\hline \multirow[t]{2}{*}{ Digital picture books } & Yes & $9(.6)$ & $9(-.6)$ & $3(-2.2)$ & $11(2.2)$ & 7.99* & .046 \\
\hline & No & $6(-.6)$ & $10(.6)$ & $9(2.2)$ & $3(-2.2)$ & & \\
\hline \multirow{2}{*}{ Technology use in writing } & Yes & $3(1.1)$ & $8(1.2)$ & $5(.8)$ & $3(-.9)$ & 3.13 & .372 \\
\hline & No & 12 (1.1) & $11(-1.2)$ & $7(-.8)$ & $11(.9)$ & & \\
\hline \multirow{2}{*}{ Word bank use for writing } & Yes & $3(-1.1)$ & $7(.6)$ & $7(2.2)$ & $2(-1.6)$ & 7.08 & .069 \\
\hline & No & 12 (1.1) & $12(-.6)$ & $5(-2.2)$ & 12 (1.6) & & \\
\hline
\end{tabular}

Note. ${ }^{*} p<.05,{ }^{* *} p<.01, d f=3$. Adjusted standardized residuals appear in parentheses beside group frequencies

To further investigate, statistical significance (See Table 9) was found in the association of teaching experience with TPACK by the Chi-square test (i.e., No technology use in speaking, $p<0.05, X^{2}=8.530$; Dubbing for animations and movies, $p<0.05, X^{2}=7.96$; No technology use in reading, $p<0.05, X^{2}=7.92$; Reading digital picture books, $\left.p<0.05, X^{2}=7.99\right)$.

Therefore, findings indicated that beginning teachers have general TK, but they lack the TPK and TPACK; teachers with over 16-years' experience with least TK, TPK, and TPACK compared with other groups. In other words, the intermediate experience level (6-15 years) teachers, especially the 6-10 years' experience level seems to have the highest level of TK, TPK, and TPACK.

\section{DISCUSSION}

The findings of this study provide evidence of the group differences among teachers with different teaching experiences in the capacity of TPACK and PD opportunities. The results revealed that the EFL teachers' level regarding TPACK application varied due to the number of PD opportunities given. The findings are discussed in more depth in the following paragraphs.

In this study, both novice teachers and experienced teachers with 16 or more years in teaching profession were found to have fewer training opportunities related to technology than other groups as well as lower TPACK. For example, Group 1 which included all beginning teachers, with most of being first-year teachers, reported that were provided with less PD training and also lacked access to the district training information. Meanwhile, they were also found to have the least knowledge of multimedia teaching methods, English learning website, and external activity website as resources to support teaching. Similarly, Group 4 teachers, who are the most experienced EFL teachers, also participated less in technology PD training, but showed the 
lowest TPACK in teaching speaking, reading and writing skills. It may be that teachers in Group 4 had little technology training early in their careers so that they are not used to teaching via technology. This study reveals that the more PD training opportunities the better TPACK skills and its application in EFL class. Therefore, we may infer that there is a casual relationship between the level of teachers' TPACK application and continuing PD training experience.

Studies have indicated that by participating in ongoing professional development teachers can learn and develop so their teaching effectiveness will improve along with student achievement (Hoesein, 2015). Schools and districts should pay more attention to and provide additional support to beginning teachers' PD. Districts also should encourage EFL teachers who have more experience to become more comfortable teaching with technology. In addition, they should ensure that the PD opportunities assist EFL teachers in developing teaching strategies in each of the language domains so that the class content could be delivered more efficiently by providing appropriate pedagogy and technology.

Additionally, contrary from the findings of other studies that more experienced teachers would have better teaching skills (Jang \& Tsai, 2012; Kini \& Podolsky, 2016), teachers who have intermediate to advanced teaching experience were found to have better TPACK skills in this study. Different cultural backgrounds and school context may account for this conflict. This finding, however, supports the results of many studies in the literature that more experienced EFL teacher with higher seniority has lower TPACK skills than teachers who have been teaching with fewer years (Akturk \& Ozturk, 2019; Ansyari, 2015; Nazari et al., 2019). The rapid development nowadays in technological use may contribute to this difference. In addition, research has found that PD training based on the TPACK framework has profound impacts on teachers' level of instructional skills cooperated with technology (Caromawati, 2017; Liu \& Kleinsasser, 2015). Thus, it can be asserted that teachers who are provided with more PD training in TPACK related training perform a higher level of teaching skills with the integration of the three domains of technology, content, and pedagogy.

\section{CONCLUSIONS AND RECOMMENDATIONS}

EFL teachers participating in this study were provided limited PD training related to TPACK. To be more specific, more experience teachers were provided less training opportunities compared with teachers who have fewer teaching experience. In addition, more experienced teachers were found to have less application of TPACK in classroom teaching than less experienced teaching. Considering that research has supported the integration of technology as effective in promoting teaching quality and enhancing students' academic performance (Ansyari, 2015) as well as enhancing students' language acquisition (Levak \& Son, 2017), it is important that professional development training be developed that helps second language teachers integrate technology into their teaching, rather than simply adding technology to the existing teaching and content domain. Teachers need regular practice making connections between technological knowledge, pedagogical knowledge, and content knowledge. This study indicates that schools and districts need to increase attention to and provide more support to EFL teachers on the resources of TPACK related PD. In this way, teachers would be benefited from the PD activities to teach more effectively and students' performance will be improved eventually by engaging actively in the EFL classroom teaching and learning.

Based on the findings of this study, there is a need to provide more PD opportunities for Chinese EFL teachers. The findings, for example, indicated that less than 50\% EFL teachers participated in PD training related to TPACK skills. Most of the training that teachers participated in was training mainly related to soft/hard-ware training (58\%). That is, teachers were trained to gain knowledge in general technology integration but do not have adequate opportunities to develop more skills in integrating technology to teach English as a second language. Also, according to the teachers' responses in this study, providing hybrid training format including both online and in-person modes might be a possible way to meet all teachers' need, since both online and in-person formats have advantages on teacher's learning. Additionally, due to teachers were not likely to apply TPACK in teaching speaking, reading, and writing skills to ELs, more PD related to these topics need to be provided. 
While the study sheds light on the impact of teacher PD opportunity on their level of TPACK, there are a few limitations of this study. First, CK, PK, and CPK, such important elements of TPACK were not include in this study, a more comprehensive study that includes all seven sections of TPACK should be investigated in future studies. Additionally, the interview data is self-reported by the participants and it was quantified for the analysis. Future studies including a more sophisticated large-scale survey instrument with both quantitative and qualitative methods may be conducted to evaluate teacher's TPACK level as well as the casual relationship between the TPACK-EFL PD and teacher's knowledge level of TPACK.

Author contributions: All authors were involved in concept, design, collection of data, interpretation, writing, and critically revising the article. All authors approve final version of the article.

Funding: The authors received no financial support for the research and/or authorship of this article.

Declaration of interest: Authors declare no competing interest.

Data availability: Data generated or analysed during this study are available from the authors on request.

\section{REFERENCES}

Akturk, A. O., \& Saka Ozturk, H. (2019). Teachers' TPACK levels and students' self-efficacy as predictors of students' academic achievement. International Journal of Research in Education and Science, 5(1), 283294.

Angelova, M., \& Zhao, Y. (2016). Using an online collaborative project between American and Chinese students to develop ESL teaching skills, cross-cultural awareness, and language skills. Computer Assisted Language Learning, 29(1), 167-185. https://doi.org/10.1080/09588221.2014.907320

Ansyari, M. F. (2015). Designing and evaluating a professional development programme for basic technology integration in English as a foreign language (EFL) classrooms. Australasian Journal of Educational Technology, 31(6), 699-712. https://doi.org/10.14742/ajet.1675

Baracaldo Guzmán, D. (2019). Technology Integration for the Professional Development of English Teachers. Tecné, Episteme y Didaxis: TED, (46), 157-168.

Bostancıoğlu, A., \& Handley, Z. (2018). Developing and validating a questionnaire for evaluating the EFL 'Total PACKage': Technological Pedagogical Content Knowledge (TPACK) for English as a Foreign Language (EFL). Computer Assisted Language Learning, 31(2), 1-27. https://doi.org/10.1080/09588221.2017.1422524

Caromawati, C. (2017). Evaluating a synchronous online teacher development program on creating call teaching materials. Indonesian EFL Journal, 3(2), 159-170. https://doi.org/10.25134/ieflj.v3i2.663

Cheng, K. H. (2017). A survey of native language teachers' technological pedagogical and content knowledge (TPACK) in Taiwan. Computer Assisted Language Learning, 30(7), 692-708. https://doi.org/10.1080/09588221.2017.1349805

Cuban, L. (2001). Oversold and underused: Computers in the classroom. Harvard University Press.

Debbagh, M., \& Jones, W. M. (2018). Examining English language teachers' TPACK in oral communication skills teaching. Journal of Educational Multimedia and Hypermedia, 27(1), 43-62.

Education informatization 2.0. (2018). Notice of the Ministry of Education on printing and distributing the education informatization 2.0 action plan. Ministry of Education of the People's Republic of China.

Golonka, E. M., Bowles, A. R., Frank, V. M., Richardson, D. L., \& Freynik, S. (2014). Technologies for foreign language learning: a review of technology types and their effectiveness. Computer Assisted Language Learning, 27(1), 70-105. https://doi.org/10.1080/09588221.2012.700315

Hoesein, E. M. (2015). Using mobile technology and online support to improve language teacher professionalism. Procedia-Social and Behavioral Sciences, 192, 491-497. https://doi.org/10.1016/j.sbspro.2015.06.076 
Hsu, L. (2016). Examining EFL teachers' technological pedagogical content knowledge and the adoption of mobile-assisted language learning: A partial least square approach. Computer Assisted Language Learning, 29(8), 1287-1297. https://doi.org/10.1080/09588221.2016.1278024

Jabbari, N., Boriack, A. W., Barohona, E., Padrón, Y. N., \& Waxman, H. C. (2017). Social networking. InJ. I. Liontas (Ed.), The TESOL encyclopedia of English language teaching (pp. 1-7). TESOL International Association and Wiley. https://doi.org/10.1002/9781118784235.eelt0430

Jang, S. J., \& Tsai, M. F. (2012). Exploring the TPACK of Taiwanese elementary mathematics and science teachers with respect to use of interactive whiteboards. Computers \& Education, 59(2), 327-338. https://doi.org/10.1016/j.compedu.2012.02.003

Kabakci Yurdakul, I., Odabasi, H. F., Kilicer, K., Coklar, A. N., Birinci, G., \& Kurt, A. A. (2012). The development, validity and reliability of TPACK-deep: A technological pedagogical content knowledge scale. Computers \& Education, 58(3), 964-977. https://doi.org/10.1016/j.compedu.2011.10.012

Karimi, M. N. (2011). The effects of professional development initiatives on EFL teachers' degree of self efficacy. Australian Journal of Teacher Education, 36(6), 4. https://doi.org/10.14221/ajte.2011v36n6.6

Kini, T., \& Podolsky, A. (2016). Does teaching experience increase teacher effectiveness? A Review of the Research (Palo Alto: Learning Policy Institute). https://doi.org/10.54300/625.642

Levak, N., \& Son, J. B. (2017). Facilitating second language learners' listening comprehension with Second Life and Skype. ReCALL, 29(2), 200-218. https://doi.org/10.1017/S0958344016000215

Li, L. (2014). Understanding language teachers' practice with educational technology: A case from China. System, 46, 105-119. https://doi.org/10.1016/j.system.2014.07.016

Liu, M. H., \& Kleinsasser, R. (2015). Exploring EFL teachers' knowledge and competencies: In-service program perspectives. Language Learning \& Technology, 19(1), 119-138.

Mishra, P., \& Koehler, M. J. (2006). Technological pedagogical content knowledge: A framework for teacher knowledge. Teachers College Record, 108(6), 1017-1054. https://doi.org/10.1111/j.14679620.2006.00684.x

Nazari, N., Nafissi, Z., Estaji, M., Marandi, S. S., \& Wang, S. (2019). Evaluating novice and experienced EFL teachers' perceived TPACK for their professional development. Cogent Education, 6(1), 1632010. https://doi.org/10.1080/2331186X.2019.1632010

Rienties, B., Lewis, T., O'Dowd, R., Rets, I., \& Rogaten, J. (2020). The impact of virtual exchange on TPACK and foreign language competence: Reviewing a large-scale implementation across 23 virtual exchanges. Computer Assisted Language Learning, 1-27. https://doi.org/10.1080/09588221.2020.1737546

SGO (Steering Group Office for Survey of Language Situation in China). (2006). Zhongguo Yuyan Wenzi Shiyong Qingkuang Diaocha Ziliao: Findings and Documents of Survey of Language Situation in China. Language Press.

Statista Research Department (2021, Mar 3). The most spoken languages worldwide 2021. https://www.statista.com/statistics/266808/the-most-spoken-languages-worldwide

Wei, R., \& Su, J. (2012). The statistics of English in China. English Today, 28(3), 10-14. https://doi.org/10.1017/\$0266078412000235

Wu, Y. T., \& Wang, A. Y. (2015). Technological, pedagogical, and content knowledge in teaching English as a foreign language: Representation of primary teachers of English in Taiwan. The Asia-Pacific Education Researcher, 24(3), 525-533. https://doi.org/10.1007/s40299-015-0240-7

Xu, X., \& Sun, Y. (2019). A Technological pedagogical content knowledge (TPACK) Framework for ESP teachers in tertiary education in China. The Asian ESP Journal, 193. 
Yuksel, I., \& Yasin, E. (2014). Cross-sectional evaluation of English language teachers' technological pedagogical content knowledge. Educational Research Quarterly, 38(2), 23.

Correspondence: Xuan Zhou, College of Education and Human Development, Texas A\&M University, TX, USA. E-mail:xuanzhou@tamu.edu 